\title{
Producción Científica de UNITEC/CEUTEC afuera de INNOVARE durante el año 2015
}

En vista que INNOVARE es el medio de comunicación de la actividad investigativa del sistema universitario UNITEC/CEUTEC, a continuación se presentan resúmenes de artículos que fueron publicados por personal docente y administrativo de UNITEC en diferentes revistas indexadas internacionales, así como en las actas de conferencias profesionales y científicas en diferentes partes del mundo durante el 2015.

\section{Bringing ERP to Small Medium Enterprises in Honduras}

Jorge Alejandro Caballero Murillo y Carlos Roberto Arias, Ph.D.

\author{
UNITEC, Honduras
}

\section{Publicado en}

The Proceedings of the 13th Latin American and Caribbean Conference for Engineering and Technology (LACCEI 2015)

\begin{abstract}
:
SMEs are the $70 \%$ of the economic base of Honduras. SMEs faces great problems managing their accounting, sales and manufacturing control, SME owners need a way to see accurate information of their companies to make decisions. When running a business using 'pencil and paper' they cannot see accurate and current information. Implementing an ERP can help gain control, simplify processes and integrate departments.
\end{abstract}

\section{Resumen:}

Las PYME representan el 70\% de la base económica de Honduras. Las PYME enfrentan serios problemas en el manejo de su contabilidad, ventas y control de manufactura, los dueños de PYME necesitan una manera de ver información precisa de sus compañías para poder tomar decisiones. Al momento de manejar un negocio usando "lápiz y papel" no pueden ver información precisa y oportuna. La implementación de un ERP puede ayudar a tomar control, simplificar procesos e integrar departamentos.

\section{Link al artículo completo:}

http://www.laccei.org/LACCEI2015-SantoDomingo/StudentPapers/SP059.pdf 


\title{
Facebook in Higher Education: The UNITEC Case
}

\author{
Carlos Roberto Arias, Ph.D. \\ UNITEC, Honduras \\ Publicado en \\ The Proceedings of the 13th Latin American and Caribbean Conference for \\ Engineering and Technology (LACCEI 2015)
}

\begin{abstract}
:
To reach our students, faculty needs to be where they can be found: online. There is no question that Internet technologies have changed the way we live, so it is obvious that there is an impact on education. Students learn differently, and furthermore they interact differently. It is imperative that education institutions recognize this reality. This paper is the result of a study made on the Universidad Tecnológica Centroamericana (UNITEC) Tegucigalpa campus to measure the penetration of Facebook in the classroom, and to explore what the usage of Facebook by UNITEC faculty and students. Results show that students are more willing than faculty to incorporate the Facebook platform to their academic life. A proposal on how to effectively use Facebook in course work will be presented, based on the findings on the experience of two years integration of Facebook in computer science courses.
\end{abstract}

\section{Resumen (traducción):}

Para alcanzar a nuestros estudiantes, los profesores tienen que estar donde se puede encontrar a los estudiantes: En línea. No hay lugar a dudas que las tecnologías que ha traído el Internet han cambiado la manera en que vivimos. Es entonces obvio que esto va a tener un impacto en la educación. Los estudiantes aprenden diferente, aunado a ello, interactúan de manera diferente. Es imperativo que las instituciones de educación reconozcan esta realidad. Este artículo es el resultado de un estudio realizado en la Universidad Tecnológica Centroamericana (UNITEC) en el campus Tegucigalpa para medir la penetración de Facebook de parte de los estudiantes y los profesores. Los resultados muestran que los estudiantes están más dispuestos que los profesores a incorporar la plataforma de Facebook en sus actividades académicas. Se presenta también una propuesta para usar efectivamente Facebook en las clases, esto basado en los descubrimientos y en la experiencia de usar Facebook durante dos años en cursos de Ingeniería en Sistemas Computacionales.

\section{Link al artículo completo:}

http://www.laccei.org/LACCEI2015-SantoDomingo/meta/RP054.html 


\title{
Population as Auditor of an Election Process in Honduras: The Case of the VotoSocial Crowdsourcing Platform
}

\author{
Carlos Roberto Arias, Ph.D. y Jorge Antonio García, M.Sc. \\ UNITEC, Honduras
}

Alejandro Corpeño, M.Sc.

Publicado en

Policy \& Internet, Vol. 7, Iss. 2, 2015

\begin{abstract}
:
For a country to become fully democratic, the majority of the population needs to be involved in the politics of that country. This requires people to be aware of what is happening, and to be able to participate in the country's political processes. VotoSocial is a crowdsourcing system launched during the 2013 Honduran government elections. It retrieved the official polling table records in digitized form from the Supreme Electoral Tribunal (the Government's elections authority) and provided them to the Internet community to be counted and the digitizations verified. VotoSocial was thereby able to verify the accuracy of the official polling results. We found no evidence of fraud in the digitization process, but statistical analysis revealed a data behavior usually associated with incremental fraud in an electoral process. VotoSocial shows that social mediapowered crowdsourcing systems can increase a population's political awareness during elections, thus providing a motive to build similar platforms in other countries with political systems marked by electoral fraud.
\end{abstract}

\section{Resumen (traducción):}

Para que un país sea completamente democrático, la mayoría de su población debe involucrarse en la política del país. Esto requiere que las personas tengan conciencia de lo que está pasado, y que participen activamente en los procesos políticos del país. VotoSocial es un sistema de "Crowdsourcing" lanzado durante las elecciones gubernamentales de Honduras del 2013. El sistema recuperaba los registros de las actas electorales de cada una de las mesas que habían sido digitalizadas por el Tribunal Supremo Electoral de Honduras (la institución a cargo de los procesos electorales en Honduras) y una vez recuperados los mostraba a la comunidad de Internet para verificar su exactitud. No encontramos evidencia de fraude en el proceso de digitalización, pero un análisis estadístico reveló un comportamiento de los datos que normalmente se asocia con fraude incremental en el proceso electoral. VotoSocial muestra que sistemas "Crowdsourcing" impulsados por los medios sociales pueden incrementar la conciencia política de la población durante un proceso electoral, proveyendo motivación para construir plataformas parecidas en otros países en los que también sucede fraude electoral.

\section{Link al artículo completo:}

http://onlinelibrary.wiley.com/doi/10.1002/poi3.86/abstract 


\title{
Assessment of Interaction in Multinational Projects: A Gender Comparison
}

\author{
Jaime Nuñez, Ph. D. y Sheila Katherine Lascano Farak, Ph. D. \\ Universidad Técnica Federico Santa María, Chile \\ Ivan E. Esparragoza, Ph. D. \\ Pennsylvania State University, EEUU \\ Jared R. Ocampo, M.Sc. \\ UNITEC, Honduras \\ Jorge W. Duque-Rivera, M.Sc. \\ Escuela Superior Técnica del Litoral, Ecuador \\ Roberto Vigano, Ph. D. \\ Politécnico di Milano, Italia
}

Publicado en

The Proceedings of the 13th Latin American and Caribbean Conference for Engineering and Technology (LACCEI 2015)

\begin{abstract}
:
The development of multinational collaborative projects in the academia is becoming a practice to educate students with global competencies. This educational approach is being used to expose students to an international experience through projectbased learning experiences in multinational settings. However, the effectiveness of this approach has not been rigorously assessed. The research team has been working in the understanding of this practice to enhance the overall experience and create a learning environment that fosters the development of global competencies. According to the literature, the interaction among distributed teams is critical in achieving the goals of the team. Therefore, the interaction of students participating in multinational collaborative projects has been a focus of interest for the research team. The aim of this work is to compare, based on the gender, the level of interaction of participants and the use of social interaction during the development of a multinational design project. This paper presents a description of the findings based on the data collected and is the beginning of a subsequent inferential analysis
\end{abstract}

\section{Resumen (traducción):}

El desarrollo de proyectos de colaboración multinacional en el ámbito académico se está convirtiendo en una práctica para educar a los estudiantes con competencias globales. Este enfoque educativo se está utilizando para exponer a los estudiantes a una experiencia internacional a través de experiencias de aprendizaje basado en proyectos en entornos multinacionales. Sin embargo, la eficacia de este enfoque no ha sido rigurosamente evaluada. El equipo de investigación ha estado trabajando en la comprensión de esta 
práctica para mejorar la experiencia en general y crear un entorno de aprendizaje que fomente el desarrollo de competencias globales. De acuerdo con la literatura, la interacción entre los equipos distribuidos es fundamental en el logro de los objetivos del equipo. Por lo tanto, la interacción de los estudiantes que participan en proyectos de colaboración multinacional ha sido un foco de interés para el equipo de investigación. El objetivo de este trabajo es comparar, basado en el género, el nivel de interacción de los participantes y el uso de la interacción social durante el desarrollo de un proyecto de diseño multinacional. Este documento presenta una descripción de los hallazgos basado en los datos recogidos y es el principio de un análisis inferencial posterior.

\section{Link al artículo completo:}

http://www.laccei.org/LACCEI2015-SantoDomingo/RefereedPapers/RP125.pdf 


\title{
Metodología para Establecer los Elementos de un Modelo de Referencia de Competitividad de Manufactura en Plantas Maquiladoras
}

\author{
Jared R. Ocampo, M.Sc. y Desiree Tejada, Ph.D. \\ UNITEC, Honduras \\ Juan Carlos Hernández, Ph.D. y Antonio Vizán, Ph.D. \\ Universidad Politécnica de Madrid, España
}

Publicado en

The Proceedings of the 13th Latin American and Caribbean Conference for Engineering and Technology (LACCEI 2015)

\section{Resumen:}

La globalización ha creado la necesidad de que la industria repiense sus estrategias y procesos para ser más competitivos y así poder permanecer en el mercado. Para lograr esta competitividad, las empresas deben establecer estrategias de fabricación que se centren en satisfacer las necesidades específicas de los clientes. Las necesidades del cliente se pueden modelar en base a la importancia que le dan a ciertas prioridades competitivas. Una empresa que entiende bien cuáles son estas prioridades y luego trabaja para hacer que su estrategia de fabricación responda a estas necesidades será capaz de posicionarse positivamente sobre sus competidores. En este trabajo se propone una metodología para identificar las prioridades competitivas del mercado maquilador, así como las dimensiones que se pueden utilizar para explicar estas prioridades metas. Para lograr esto, se llevó a cabo un análisis extenso de la literatura, así como un estudio piloto para validar las prioridades y dimensiones a utilizar, así como la metodología propuesta.

\begin{abstract}
:
Globalization has created the need for industry to rethink their strategies and processes to become more competitive to be able to stay in business. To achieve this level of competitiveness, companies must establish manufacturing strategies that focus on meeting the specific needs of customers. Customer needs can be modeled based on the importance given to certain competitive priorities. A company that understands well what these priorities are and then works to make its manufacturing strategy responsive to these needs will be able to positively position itself over its competitors. This paper proposes a methodology to identify the competitive priorities of the maquiladora market as well as the dimensions that can be used to explain these priority goals. To achieve this, we carried out an extensive analysis of the literature as well as a pilot study to validate the priorities and dimensions to be used and the proposed methodology.
\end{abstract}

\section{Link al artículo completo:}

http://www.laccei.org/LACCEI2015-SantoDomingo/RefereedPapers/RP159.pdf 


\title{
Assessment of Students' Interactions in Multinational Collaborative Design Projects
}

\author{
Ivan E. Esparragoza, Ph. D. \\ Pennsylvania State University, EEUU \\ Sheila Katherine Lascano Farak, Ph. D. y Jaime Nuñez, Ph. D. \\ Universidad Técnica Federico Santa María, Chile \\ Jared R. Ocampo, M.Sc. \\ UNITEC, Honduras \\ Roberto Vigano, Ph. D. \\ Politécnico di Milano, Italia \\ Jorge W. Duque-Rivera, M.Sc. \\ Escuela Superior Técnica del Litoral, Ecuador \\ Carlos A. Rodríguez, M. Sc. \\ EAFIT, Colombia
}

Publicado en

International Journal of Engineering Education, Vol. 31, Iss. 5, 2015

\begin{abstract}
:
Exposing students to international experiences is becoming a common practice to prepare students with global capabilities. One pedagogical activity used to promote global competencies is the participation of students in multinational design projects. This is a problem-based learning approach in an international setting, where students get immersed in the solution of an engineering design task while they work in teams and collaborate with international partners. The main goal of these projects is to foster international collaboration and to offer an opportunity to the students to develop professional skills through international teamwork effort in the solution of a design problem. However, a real challenge of this practice has been to create an effective interaction among the students participating in this type of projects and to maintain the flow of information, and student engagement in the project and in their learning process. The main objective of this work is to investigate the sociotechnical interaction of engineering students working in a multinational collaborative project and the role of information technology tools and the nature of the interaction in this experience. For this purpose an assessment tool was developed and used to determine the interaction among the students (frequency, quantity and quality), the value of social interaction in the flow of the interaction, and the impact of the interaction in the development of the project. The main findings of this instrument are presented in this work.
\end{abstract}




\section{Resumen (traducción):}

La exposición de estudiantes a experiencias internacionales se está convirtiendo en una práctica común para preparar a los estudiantes con capacidades globales. Una actividad pedagógica usada para promover competencias globales es la participación de los estudiantes en proyectos de diseño multinacional. Este es un enfoque de aprendizaje basado en problemas en un entorno internacional, donde los estudiantes se sumergen en la solución de una tarea de diseño de ingeniería mientras trabajan en equipo y colaboran con compañeros internacionales. La meta principal de estos proyectos es fomentar la colaboración internacional y ofrecer una oportunidad a los estudiantes de desarrollar habilidades profesionales a través del trabajo en un equipo internacional para la solución de un problema de diseño. Sin embargo, un verdadero desafío de esta práctica ha sido crear una interacción eficiente entre los estudiantes que participan en este tipo de proyectos y mantener el flujo de información y la participación de los estudiantes en el proyecto y en su aprendizaje. El principal objetivo de este trabajo es investigar las interacciones socio-técnicas de los estudiantes de ingeniería participando en un proyecto de colaboración multinacional y el papel de las herramientas de tecnología de la información y la naturaleza de las interacciones en esta experiencia. Para este propósito se desarrolló y utilizó una herramienta para determinar la interacción entre los estudiantes (frecuencia, cantidad y calidad), el valor de la interacción social en el flujo de la interacción, y el impacto de la interacción en el desarrollo del proyecto. Las principales conclusiones de este instrumento se presentan en este trabajo.

\section{Link al artículo completo:}

\section{http://www.ijee.ie/contents/c310515.html}




\title{
Assessment of interaction in multinational projects: A comparison based on geographical location
}

\author{
Ivan E. Esparragoza, Ph. D. \\ Pennsylvania State University, EEUU \\ Jaime Nuñez, Ph. D. y Sheila Katherine Lascano Farak, Ph. D. \\ Universidad Técnica Federico Santa María, Chile \\ Jared R. Ocampo, M.Sc. \\ UNITEC, Honduras \\ Roberto Vigano, Ph. D. \\ Politécnico di Milano, Italia \\ Jorge W. Duque-Rivera, M.Sc. \\ Escuela Superior Técnica del Litoral, Ecuador
}

\section{Publicado en}

Proceeding of the 2015 International Conference on Interactive Collaborative Learning (ICL)

\begin{abstract}
:
Multinational teams working in engineering solutions are becoming a common practice in many industries around the world because companies are interested in capitalizing on human resources dispersed globally. This practice has increased significantly due to advancements in information and communication technologies (ICT). The effectiveness of those geographically dispersed teams has been a topic of interest for the authors of this paper particularly the interaction among the team members since the literature recognizes that teams achieve better results when the interaction is strong and the social level of interaction is significant; additionally, that the working environment is more conducive to a positive experience when social interaction is built. This paper presents a description of the findings based on the data collected in a study done on the interaction of teams in a multinational collaborative design project carried out by students from six different countries dispersed in the US, Latin America and Europe. The main objective of this study is to use an assessment tool to evaluate the interaction among the students focusing in its nature, preferred communication tools and perceived value, with a special interest in the observed differences based on cultural backgrounds due to geographical location.
\end{abstract}

\section{Resumen (traducción):}

Equipos multinacionales que trabajan en soluciones de ingeniería se están convirtiendo en una práctica común en muchas industrias a nivel mundial, porque las empresas están interesadas en la capitalización de los recursos humanos dispersos por el mundo. Esta práctica se ha incrementado de manera significativa debido a los avances en tecnologías de información y comunicación (TIC). La eficacia de esos equipos dispersos geográficamente ha sido un tema de interés para los autores de este trabajo, en particular 
la interacción entre los miembros del equipo, ya que la literatura reconoce que estos logran mejores resultados cuando la interacción es fuerte y el nivel social de interacción es significativo; además de que el ambiente de trabajo es más propicio para una experiencia positiva cuando se construye la interacción social. En este trabajo se presenta una descripción de los resultados en base a los datos recogidos en un estudio realizado a la interacción de los equipos en un proyecto de diseño de colaboración multinacional, llevado a cabo por los estudiantes de seis países diferentes, dispersos en los EE.UU., América Latina y Europa. El objetivo principal de este estudio es el uso de una herramienta de evaluación que permita evaluar la interacción entre los estudiantes entrada en su naturaleza, las herramientas de comunicación preferidas y el valor percibido, con un interés especial en las diferencias observadas en base a los antecedentes culturales debido a su ubicación geográfica.

\section{Link al artículo completo:}

http://ieeexplore.ieee.org/xpl/articleDetails.jsp?tp=\&arnumber $=7318052 \&$ url $=$ http $\% 3 \mathrm{~A}$ \%2F\%2Fieeexplore.ieee.org\%2Fxpls\%2Fabs_all.jsp\%3Farnumber\%3D7318052 


\title{
Fabricación de una Prótesis Humana utilizando una impresora 3D en Honduras
}

\author{
Ricardo D. Borjas y Wifredo C. Flores, Ph.D. \\ UNITEC, Honduras
}

Publicado en

The Proceedings of the XXV Congreso Panamericano de Ingeniería Mecánica, Eléctrica, Industrial y ramas afines (COPIMERA 2015)

\section{Resumen:}

En vista de contar con un sistema de salud pública precario, la población hondureña se encuentra en la necesidad de buscar alternativas para suplir sus necesidades de salud, esto es particularmente importante para la población con discapacidades físicas. Para el Hospital San Felipe, el cual es el centro de prótesis más grande del país, es imposible cumplir con la demanda existente, ya que alrededor de 1,800 personas al año requieren un miembro prostético, sólo en este centro. Además de la alta demanda y escasez de materiales, el centro se dedica exclusivamente a la producción de prótesis sobre y bajo rodilla, dejando a un lado a pacientes cuyos requerimientos prostéticos son distintos.

Es aquí donde se observa la posibilidad de implementar prótesis elaboradas utilizando impresoras 3D, que no sólo aliviarían la mora de prótesis, sino que también reducirían los precios y el tiempo de creación de las mismas. Utilizando este proceso, la creación de prótesis de manos se convierte en una posibilidad viable.

Este artículo pretende explicar el funcionamiento de este proceso y exponer las ventajas del mismo, haciendo énfasis especial en la factibilidad y accesibilidad de las prótesis de manos en Honduras.

\begin{abstract}
:
In view of having a poor public health system, the Honduran population is in the need of finding alternatives to meet their health needs, this is particularly important for people with physical disabilities. For the San Felipe Hospital, which is country's largest center for prosthesis it is impossible to meet the demand, since about 1,800 people each year require a prosthetic limb, only at this center. In addition to the high demand and shortage of materials, the center is dedicated exclusively to the production of above and below knee prosthesis, leaving aside prosthetic patients whose requirements are different.

This is where the possibility of implementing prostheses made using 3D printers, which not only alleviate the arrears of prosthesis, but also reduce the price and time of creating them, is observed. Using this process, the creation of hand prostheses becomes a viable possibility.
\end{abstract}


This article aims to explain how this process works and exposes the advantages thereof, with particular emphasis on the feasibility and accessibility of hand prostheses in Honduras.

Link al artículo completo:

https://www.researchgate.net/publication/281784966_Fabricacion_de_una_Protesis_Hu mana_utilizando_una_impresora_3D_en_Honduras

"LA REVISTA INNOVARE NO SE HACE RESPONSABLE EN NINGÚN CASO DE LOS CONTENIDOS, DATOS, CONCLUSIONES U OPINIONES VERTIDAS EN LOS ARTÍCULOS PUBLICADOS, SIENDO ESTA RESPOSABILIDAD EXCLUSIVA DEL (DE LOS) AUTOR (AUTORES)" 